\title{
Evaluation of online learning process of intern dental students during the Covid-19 pandemic period: A survey
}

\author{
Covid-19 pandemisi döneminde diş hekimliği \\ fakültesi öğrencilerinin online öğrenme sürecinin \\ değerlendirilmesi: Bir anket çalışması
}

Gaye KESER (D)

Filiz NAMDAR PEKINER (D)

Department of Oral Diagnosis and Maxillofacial Radiology, Marmara University, Faculty of Dentistry, İstanbul, Turkey
${ }^{*}$ This study was presented as on oral presentation in $2^{\text {nd }}$ INTERNATIONAL CONGRESS OF MULTIDISCIPLINARY STUDIES

IN MEDICAL SCIENCESthat was held on February $13-14^{\text {th }}, 2021$, Ankara, Turkey.

Received/Geliş Tarihi: 28.07.2021 Accepted/Kabul Tarihi: 05.11.2021

Corresponding Author/Sorumlu Yazar: Gaye Keser

E-mail: gayekeser@hotmail.com gaye.sezgin@marmara.edu.tr

Cite this article: Keser G, Namdar Pekiner F. Evaluation of online learning process of intern dental students during the Covid-19 pandemic period: A survey. Curr Res Dent Sci. 2022; 32(1): 1-4

\section{cc) $(9)$}

Content of this journal is licensed under a Creative Commons Attribution-NonCommercial 4.0 International License.

\begin{abstract}
Objective: Due to the COVID-19 epidemic, dental students have had to put their clinical training on hold and rely on online learning. The purpose of this research is to look at the influence of the COVID-19 pandemic on intern dental students and to assess their views on online learning.
\end{abstract}

Methods: An online survey was conducted consisting of 7 questions using Google Forms and circulated among $754^{\text {th }}$ and $605^{\text {th }}$ grade students at Marmara University, Faculty of Dentistry. The survey consisted of questions regarding participants' attitudes toward online education. IBM SPSS Statistics 25.0 (IBM SPSS, Turkey) program is used for statistical analysis.

Results: It was found that most of the students (71.9\%) felt comfortable with technology-based education, and 45.9\% felt less motivated to follow online education. A statistically significant difference was found between 4 th and 5 th grade students who thought that they missed their educational experiences due to the pandemic and that face-to-face compensation programs should be made for some of the lessons $(P<.05)$.

Conclusion: The data show that most of the students have a positive attitude towards education using the online system and technology.

Keywords: COVID-19, dental students, online learning

öz

Amaç: COVID-19 salgını ile ilişkili kısıtlamalar dişhekimliği öğrencilerinin klinik eğitimlerinin askıya alınması ve uzaktan öğrenme yöntemlerine geçilmesine sebep olmuştur. Bu çalışmanın amacı, COVID-19 pandemisinin stajyer dişhekimliği öğrencileri üzerindeki etkisini araştırmak ve öğrencilerin çevrimiçi eğitime bakış açılarını değerlendirmektir.

Yöntemler: Çalışmamızda Marmara Üniversitesi Diş Hekimliği Fakültesi'nde öğrenim gören 75 4. ve 60 5. sınıf öğrencisine Google Forms kullanılarak katılımcıların uzaktan eğitim/çevirimiçi eğitim ile ilgili tutum ve algılarına ilişkin 7 sorudan oluşan online anket uygulanmıştır. İstatistiksel analiz için IBM SPSS Statistics 25.0 (IBM SPSS, Türkiye) programı kullanılmıştır.

Bulgular: Öğrencilerin çoğunun (\%71.9) teknoloji tabanlı eğitimle kendini rahat hissettiği, \%45.,9'unun uzaktan eğitimi takip etmede daha az motive olmuş hissettiği saptanmıştır. 4. ve 5. Sınıf öğrencileri arasında pandemi nedeniyle eğitim deneyimlerini kaçırdığını ve derslerin bir kısmı için yüz yüze telafi programlarının yapılması gerektiğini düşünen öğrenciler arasında istatistiksel olarak anlamı fark bulgulanmıştır $(P<, 05)$.

Sonuç: Veriler, öğrencilerin çoğunun çevrimiçi sistem ve teknoloji kullanılarak yapılan eğitime karşı olumlu tutum sergilediklerini göstermektedir.

Anahtar Kelimeler: COVID-19, dişhekimliği öğrencileri, çevrimiçi eğitim

\section{INTRODUCTION}

The COVID-19 epidemic has disrupted classes at a number of institutions, particularly in medical and dentistry schools, where practical instruction is the routine. To ensure the safety of students, instructors, and patients, face-to-face sessions have been suspended in numerous countries, including Turkey. Current technology has made electronic learning (e-learning/online education) the major way of teaching the curriculum to decrease the impact of the COVID-19 epidemic on the educational process. ${ }^{1}$ Online education is defined as the use of information technology to improve educational quality. ${ }^{1,2}$

For about a year, online teaching has been widely used in the training of undergraduate and graduate students for theoretical courses in dental faculties. Accessibility, suitable techniques, course material, and assessment criteria all play a role in the effectiveness of online education. E-learning, like any other 
teaching method, has benefits and drawbacks for both students and teachers. ${ }^{2-4}$ Aside from the epidemiological advantages of online schooling during the COVID-19 pandemic, additional advantages worth highlighting include lower costs and more access to materials, regardless of place or time..$^{5-7}$ Other disadvantages of online classrooms include internet access difficulties, poor internet connection quality, and participants' lack of digital skills. Some factors, such as schedule flexibility, might be a hindrance, especially for students who struggle with self-control. ${ }^{8-11}$

In our country, education processes in the field of dentistry have gained an online dimension with the COVID-19 pandemic.12,13 This change included postgraduate education processes as in undergraduate education, and face-to-face education at all levels was suspended in dentistry faculties as of mid-March 2020, and trainings and exams were continued online. ${ }^{12}$ During the COVID-19 pandemic process, it has been a matter of debate whether the theoretical courses were applied online and whether they were as effective as face-to-face training. ${ }^{14-17}$ Practical training, which forms the basis of clinical education of dentistry students, are important factors in all education processes, especially patient follow-up and case-based learning. In a study evaluating this new situation brought about by the COVID-19 pandemic, a questionnaire was applied to a total of 301 dentistry students, and it was determined that $44.2 \%$ of the 301 students who participated preferred distance/online education to in-class education. ${ }^{18}$ Another research in Poland found that the major benefits of online learning were ongoing access to online resources (69\%), studying at one's own speed (64\%), and a pleasant atmosphere (54\%). The biggest drawbacks, according to the majority of responders, are a lack of connection with patients (70\%) and technical issues with computer technology equipment (54\%). Moreover, online learning was less successful than face-to-face learning in terms of improving abilities, despite the fact that there was no statistical difference in opinions on the potential of the learning technique to gain knowledge. ${ }^{1,2}$
Against the potential of recurrence of pandemics or other emergencies that require an immediate transition to the online learning process, it is very important to examine and evaluate online education experiences in order to better prepare and adapt to these processes. The purpose of this survey study is to evaluate the perspectives of dental students on the situations brought about by the pandemic process and their views on online theoretical and clinical training.

\section{MATERIALAND METHODS}

An online survey was conducted consisting of 7 questions using Google Forms and circulated among 75 (55.6\%) 4th and 60 (44.4\%) 5th grade students at Marmara University, Faculty of Dentistry. The survey consisted of questions regarding participants' attitudes toward online education.

\section{Statistical Analysis}

For statistical analysis, IBM SPSS Statistics 25.0 (IBM Corp., USA) is performed. In addition to descriptive statistical approaches (mean, standard deviation, frequency), the Chi-Square test was applied to investigate qualitative data, with significance determined at the $p<0.05$ level.

\section{RESULTS}

The study was conducted with a total of 135 students, 47 (34.8\%) males and $88(65.2 .9 \%)$ females. The average age of students is 23. $28 \pm 1.22$.

The majority of $4^{\text {th }}$ grade participants (81.3\%) lost educational opportunities as a result of the lockdown, which was considerably greater than the $5^{\text {th }}$ grades $(p<0.05)$. More than half of students, particularly fifth-year students $(68.3 \%)$, believe that online assessment is an useful way to evaluate. Furthermore, $41.3 \%$ of fourth-grades are engaged and inspired to continue with remote e-learning. In our study, $60 \%$ of fifth-grades prefer online lectures to face-to-face lectures, and the majority of fourth- and fifthgrades are comfortable with technology-based education. Significantly higher percentage of $4^{\text {th }}$ year $(46,7 \%)$ compared to $5^{\text {th }}$

Table 1. Evalution of participants answers among grades

\begin{tabular}{|c|c|c|c|c|c|c|c|c|c|c|c|c|}
\hline & & \multicolumn{6}{|c|}{ Grade } & \multicolumn{5}{|c|}{ Gender } \\
\hline & & \multicolumn{2}{|c|}{$4^{\text {th }}$ grade } & \multicolumn{2}{|c|}{$5^{\text {th }}$ grade } & \multicolumn{2}{|l|}{ Total } & \multicolumn{2}{|c|}{ Male } & \multicolumn{2}{|c|}{ Female } & \multirow[b]{2}{*}{$P$ value } \\
\hline & & $\mathrm{N}$ & $\%$ & $\mathrm{~N}$ & $\%$ & $\%$ & $P$ value & $\mathrm{N}$ & $\%$ & $\mathrm{~N}$ & $\%$ & \\
\hline \multirow{3}{*}{$\begin{array}{l}\text { 1. Do you believe the COVID-19 epidemic caused } \\
\text { you to lose out on educational opportunities? }\end{array}$} & Yes & 61 & $81,3 \%$ & 37 & $61,7 \%$ & $72,6 \%$ &, $037^{*}$ & 28 & $59,6 \%$ & 70 & $79,5 \%$ &, $046^{*}$ \\
\hline & No idea & 1 & $1,3 \%$ & 1 & $1,7 \%$ & $1,5 \%$ & & 1 & $2,1 \%$ & 1 & $1,1 \%$ & \\
\hline & No & 13 & $17,3 \%$ & 22 & $36,7 \%$ & $25,9 \%$ & & 18 & $38,3 \%$ & 17 & $19,3 \%$ & \\
\hline \multirow{3}{*}{$\begin{array}{l}\text { 2. Do you believe online examination/test is an } \\
\text { useful way to assess students? }\end{array}$} & Yes & 43 & $57,3 \%$ & 41 & $68,3 \%$ & $62,2 \%$ & ,159 & 29 & $61,7 \%$ & 55 & $62,5 \%$ & ,822 \\
\hline & No idea & 11 & $14,7 \%$ & 3 & $5,0 \%$ & $10,4 \%$ & & 4 & $8,5 \%$ & 10 & $11,4 \%$ & \\
\hline & No & 21 & $28,0 \%$ & 16 & $26,7 \%$ & $27,4 \%$ & & 14 & $29,8 \%$ & 23 & $26,1 \%$ & \\
\hline \multirow{3}{*}{$\begin{array}{l}\text { 3. Do you think that clinical / practical cases } \\
\text { presented in online education have a positive value } \\
\text { on your education? }\end{array}$} & Yes & 44 & $58,7 \%$ & 45 & $75,0 \%$ & $65,9 \%$ & ,104 & 31 & $66,0 \%$ & 58 & $65,9 \%$ & \\
\hline & No idea & 12 & $16,0 \%$ & 4 & $6,7 \%$ & $11,9 \%$ & & 5 & $10,6 \%$ & 11 & $12,5 \%$ & ,935 \\
\hline & No & 19 & $25,3 \%$ & 11 & $18,3 \%$ & $22,2 \%$ & & 11 & $23,4 \%$ & 19 & $21,6 \%$ & \\
\hline \multirow{3}{*}{$\begin{array}{l}\text { 4. Did following up with remote e-learning make } \\
\text { you feel more involved and motivated? }\end{array}$} & Yes & 31 & $41,3 \%$ & 26 & $43,3 \%$ & $42,2 \%$ &, 523 & 18 & $38,3 \%$ & 39 & $44,3 \%$ &, 077 \\
\hline & No idea & 11 & $14,7 \%$ & 5 & $8,3 \%$ & $11,9 \%$ & & 7 & $14,9 \%$ & 9 & $10,2 \%$ & \\
\hline & No & 33 & $44,0 \%$ & 29 & $48,3 \%$ & $45,9 \%$ & & 22 & $46,8 \%$ & 40 & $45,5 \%$ & \\
\hline \multirow{3}{*}{$\begin{array}{l}\text { 5. Do you prefer online classes to in-person } \\
\text { classes? }\end{array}$} & Yes & 37 & $49,3 \%$ & 36 & $60,0 \%$ & $54,1 \%$ & ,309 & 24 & $51,1 \%$ & 49 & $55,7 \%$ &, 077 \\
\hline & No idea & 12 & $16,0 \%$ & 5 & $8,3 \%$ & $12,6 \%$ & & 10 & $21,3 \%$ & 7 & $8,0 \%$ & \\
\hline & No & 26 & $34,7 \%$ & 19 & $31,7 \%$ & $33,3 \%$ & & 13 & $27,7 \%$ & 32 & $36,4 \%$ & \\
\hline \multirow{3}{*}{$\begin{array}{l}\text { 6. Do you think all of this technology-based } \\
\text { schooling is beneficial for you? }\end{array}$} & Yes & 54 & $72,0 \%$ & 43 & $71,7 \%$ & $71,9 \%$ &, 717 & 39 & $83,0 \%$ & 58 & $65,9 \%$ & ,096 \\
\hline & No idea & 6 & $8,0 \%$ & 7 & $11,7 \%$ & $9,6 \%$ & & 2 & $4,3 \%$ & 11 & $12,5 \%$ & \\
\hline & No & 15 & $20,0 \%$ & 10 & $16,7 \%$ & $18,5 \%$ & & 6 & $12,8 \%$ & 19 & $21,6 \%$ & \\
\hline \multirow{3}{*}{$\begin{array}{l}\text { 7. When the COVID-19 pandemic is over, do you } \\
\text { think face-to-face compensation programs should } \\
\text { be made for some of the lectures? }\end{array}$} & Yes & 35 & $46,7 \%$ & 15 & $25,0 \%$ & $37,0 \%$ &, $013^{*}$ & 12 & $25,5 \%$ & 38 & $43,2 \%$ & ,084 \\
\hline & No idea & 10 & $13,3 \%$ & 6 & $10,0 \%$ & $11,9 \%$ & & 5 & $10,6 \%$ & 11 & $12,5 \%$ & \\
\hline & No & 30 & $40,0 \%$ & 39 & $65,0 \%$ & $51,1 \%$ & & 30 & $63,8 \%$ & 39 & $44,3 \%$ & \\
\hline
\end{tabular}

Chi square test $\mathrm{p}<0.05$ 
year dental students (25\%) think that face-to-face compensation programs should be made for some of the lectures $(p<0.05)$.

Of 135 students, $79.5 \%$ claimed they lost educational opportunities as a result of the lockdown, which was substantially greater than male students $(p<0.05)$. More than half of students, especially female students (62.5\%), believe that online assessment is an useful way to evaluate. Additionally, $44.3 \%$ want to continue their education through remote e-learning, and the majority of female and male students feel comfortable with technology-based education (Table 1).

\section{DISCUSSION}

The COVID-19 outbreak has caused in major university closures throughout the world, affecting millions of students. To keep academic courses going while reducing congestion and the risk of illness spreading, teaching and learning activities were abruptly converted to virtual modalities. While remote access is especially important during the COVID-19 epidemic, it may also save money on lodging and transportation in other situations. 1,19,20 Learning materials can be promptly supplied to students, standardized, and updated if necessary, owing to e-learning. ${ }^{21}$

Amir et al. ${ }^{18}$ evaluated the student viewpoint of face to face and online learning during the COVID-19 lockdown in the undergraduate dentistry studies program. A total of 301 students took part in the survey after receiving an online questionnaire. Student preferences were impacted by the length of their studies. When compared to their seniors, a higher percentage of first-year students selected distance learning $(p<0.001)$. For group discussions, students preferred classroom learning since remote learning made communication more difficult and gave less learning experience. Despite the fact that they felt distant learning provided a more efficient learning approach (52.6\%), more time to study (87.9\%), and more time to analyze study materials, just $44.2 \%$ chose it over classroom learning (87.3\%). In our study, $49.3 \%$ of $4^{\text {th }}$ grade and $60.0 \%$ of $5^{\text {th }}$ grade students preferred distance learning over face to face learning. Moreover $57.3 \%$ of $4^{\text {th }}$ and $68.3 \%$ of $5^{\text {th }}$ grade students and $61.7 \%$ of males and $62.5 \%$ of females in our research think that online assessment is an ideal choice for evaluation. This finding was lower than those of previous studies comparing online and conventional learning techniques, which found a greater preference for remote learning over traditional methods. ${ }^{22,23}$

During COVID-19, Özdede and Şahin ${ }^{24}$ assessed the perspectives and anxiety levels of dentistry students. Students from a dentistry faculty completed a questionnaire that included COVID-19 and online education opinions. The survey included 143 preclinical and 106 clinical students. With the change to face-to-face education, the majority of students (81.1\%) expressed anxiety that lessons would be held in groups. The majority of the participants (69.9\%) said that the prospect of graduating late makes them nervous.

Hattar et al..$^{25}$ examined the influence of quarantine on dental graduates' self-perceived readiness and the efficacy of online education from the perspective of students. A response rate of $72 \%$ was achieved in the survey. As a result of the lockout, the majority of students (77\%) missed out on educational opportunities. More than half said they were less inspired to continue performing remote e-learning and that online evaluation isn't a suitable way to assess students. Online group discussions were useful to a large majority of students (66\%), and $67 \%$ of students preferred online lectures over theatrical lectures. The quarantine, according to the majority of students, especially $5^{\text {th }}$ year students $(78.7 \%)$ $(p<0.001)$, increased their collaboration with their peers.
The two methods of presenting material to students are self-directed and instructor-led learning. Self-directed e-learning empowers students to take charge of their own learning. Peine et al. ${ }^{26}$ recently discovered that self-directed e-learning outperforms traditional face-to-face learning. Another research looked at how students felt about online classrooms throughout the epidemic. ${ }^{1,27-29}$ Learning from actual patients in a clinical context is critical for medical education, and online learning cannot entirely replace it. Whereas, in our study $58,7 \%$ of 4 th grades and $75,0 \%$ of 5 th grades stated that clinical / practical cases presented in online education have a positive value on their education.

Koçak Büyükdere ${ }^{30}$ looked into dentistry students' learning patterns in order to discover teaching techniques using two distinct learning styles and to see if the learning type changed with the clinical training. A total of 207 students participated in the study and the author reported that in both preclinic and clinic group the ideal learning style is the connection of the active experimental and abstract conceptial construction.

E-learning needs a strong internet connection as well as the appropriate software. ${ }^{31-33}$ Before and throughout an online course, students and lecturers should be familiar with the equipment. In a study by Samra et al..$^{34}$ most of the participants highlighted a typical disadvantage as the loss of connection during classes owing to poor or inconsistent network availability and interruptions. In our survey, the majority of $4^{\text {th }}$ and $5^{\text {th }}$ grade children felt at ease with all of this technology-based teaching.

Aside from the apparent advantages, remote learning has significant drawbacks. Distraction, complex technology, restricted social connection, and greater difficulty in staying in contact with teachers are just a few of the factors that might sabotage distance learning's effectivenes. ${ }^{35}$

Our study had some limitations. The results of this study revealed key insights that will help to enhance and create learning techniques in the future. However, there were several limitations to this investigation. For starters, the study's generalizability was hampered by the use of data from a single university and for only intern dental students. Second, while students were invited to participate in this study, it was entirely optional. Future studies from a broader viewpoint are required.

\section{CONCLUSION}

The impact of the epidemic on the whole educational system was unexpected and dramatic. Due of the short notice, we were unable to provide traditional education and were left with few resources and alternatives. Yet, the findings showed that, despite certain obstacles, undergraduate dentistry students were able to adjust to new remote learning methods and agreed that distance learning was more efficient than classroom learning.

Ethics Approval: The study protocol of this study was approved by the Marmara University Faculty of Medicine Non-Interventional Clinical Research Ethics Committee with on 02.07.2021 with protocol number 09.2021.819.

Peer-review: Externally peer-reviewed.

Author Contributions: Concept - G.K., F.N.P.; Design - G.K., F.N.P.; Supervision - G.K., F.N.P.; Resources - G.K., F.N.P.; Materials - G.K., F.N.P.; Data Collection and/or Processing - G.K., F.N.P.; Analysis and/or Interpretation - G.K., F.N.P.; Literature Search - G.K., F.N.P.; Writing Manuscript - G.K., F.N.P.; Critical Review - G.K., F.N.P. 
Conflict of Interest: The authors have no conflicts of interest to declare.

Financial Disclosure: The authors declared that this study has received no financial support.

Etik Komite Onayı: Bu çalışma için etik komite onayı Marmara Üniversitesi'nden (Tarih: 02.07.2021 Protokol No: 09.2021.819) alınmıştır.

Yazar Katkıları: Fikir - G.K., F.N.P.; Tasarım - G.K., F.N.P.; Denetleme - G.K., F.N.P.; Kaynaklar - G.K., F.N.P.; Malzemeler - G.K., F.N.P.; Veri Toplanması ve/ veya Işlemesi - G.K., F.N.P.; Analiz ve/veya Yorum - G.K., F.N.P.; Literatür Taraması - G.K., F.N.P.; Yazıyı Yazan - G.K., F.N.P.; Eleştirel Inceleme - G.K., F.N.P.

Hakem Değerlendirmesi: Dış bağımsız.

Çıkar Çatışması: Yazarlar çıkar çatışması bildirmemişlerdir.

Finansal Destek: Yazarlar bu çalışma için finansal destek almadıklarını beyan etmişlerdir.

\section{REFERENCES}

1. Baczek M, Zaganczyk-Baczek M, Szpringer M, Jaroszynski A, Wozakowska-Kapłon B. Students' perception of online learning during the COVID-19 pandemic: a survey study of Polish medical students. Medicine. 2021;100(e24821):7.

2. Howlett D, Vincent T, Gainsborough N, et al. Integration of a casebased online module into an undergraduate curriculum: what is involved and what is effective? e-Learning. 2009;6(4):372-384.

3. Blissitt AM. Blended learning versus traditional lecture in introductory nursing pathophysiology courses. J Nurs Educ. 2016;55(4):227230.

4. Sadeghi R, Sedaghat MM, Sha Ahmadi F. Comparison of the effect of lecture and blended teaching methods on students' learning and satisfaction. J Adv Med Educ Prof. 2014;2(4):146-150.

5. Cook D, Triola MM. What is the role of e-learning? Looking past the hype. Med Educ. 2014;48(9):930-937.

6. Salem $\mathrm{AH}$. Randomized controlled trial of simulation-based teaching versus traditional clinical instructions in nursing: a pilot study among critical care nursing students. Int J Nurs Educ. 2015;7(2):277.

7. Chumley-Jones HS, Dobbie A, Alford CL. Web-based learning: sound educational method or hype? A review of the evaluation literature. Acad Med. 2002;77(Suppl 10):86-93.

8. Niebuhr V, Niebuhr B, Trumble J, et al. Online faculty development for creating E-learning materials. Edu Health. 2014;27(3):255-261.

9. Dyrbye L, Cumyn A, Day H, et al. A qualitative study of physicians' experiences with online learning in a master's degree program: benefits, challenges, and proposed solutions. Med Teach. 2009;31(2):4046.

10. Bediang G, Stoll B, Geissbuhler A, et al. Computer literacy and e-learning perception in Cameroon: the case of Yaounde Faculty of Medicine and Biomedical Sciences. BMC Med Edu. 2013;13(1):1-8.

11. Attardi SM, Rogers KA. Design and implementation of an online systemic human anatomy course with laboratory. Anat Sci Educ. 2015;8(1):53-62.

12. Demirel A, Önder NS, Topaloğlu P, Sarı Ş. Pedodonti Lisansüstü Eğitimine COVID-19 Pandemisinin Etkileri: Bir Anket Çalışması. Selcuk Dent J. 2021;8(3):163-172.

13. Kılıçarslan MA. Covid-19 Pandemisi Sürecinde Diş Hekimliği Uygulamaları. Sağlıkta Kalite ve Akreditasyon Dergisi. 2020;3(1):41-47.

14. Hung M, Licari FW, Hon ES, et al. In an era of uncertainty: Impact of COVID-19 on dental education. J Dent Educ. 2021;85(2):148-156.

15. Gaudin A, Arbab-Chirani R, Pérez F. Effect of COVID-19 on Dental Education and Practice in France. Front Dent Med. 2020;1:1-4.
16. Peres KG, Reher P, Castro RD, Vieira AR. COVID-19-related challenges in dental education: experiences from Brazil, the USA, and Australia. Pesqui Bras Odontopediatria Clín Integr. 2020;20(Supp1):e0131.

17. Chang T, Hong G, Paganelli C, Phantumvanit P, Chang W, Shieh $Y$, Hsu M. Innovation of dental education during COVID-19 pandemic. J Dent Sci. 2021;16(1):15-20.

18. Amir LR, Tanti I, Maharani DA, et al. Student perspective of classroom and distance learning during COVID-19 pandemic in the undergraduate dental study program Universitas Indonesia. BMC Med Educ. 2020;20:392.

19. Stain SC, Mitchell M, Belue R, et al. Objective assessment of video conferenced lectures in a surgical clerkship. Am J Surg. 2005;189(1):81-84.

20. Amesse LS, Callendar E, Pfaff-Amesse T, et al. Evaluation of computer aided strategies for teaching medical students prenatal ultrasound diagnostic skills. Med Educ Online. 2008;13(1):13.

21. Zehry K, Halder N, Theodosiou L. E-Learning in medical education in the United Kingdom. Procedia Soc Behav Sci. 2011;15:3163-3167.

22. Kavadella A, Tsiklakis K, Vougiouklakis G, Lionarakis A. Evaluation of a blended learning course for teaching oral radiology to undergraduate dental students. Eur J Dent Educ. 2012;16:e88-95.

23. Jeganathan S, Fleming PS. Blended learning as an adjunct to tutor-led seminars in undergraduate orthodontics: a randomised controlled trial. Br Dent J. 2020;228:371-375.

24. Özdede M, Sahin SC. Views and anxiety levels of Turkish dental students during the COVID-19 pandemic. J Stomatol. 2020;73(3):123128

25. Hattar S, AlHadidi A, Sawair FA, Alraheam IA, El-Ma'aita A, Wahab FK. Impact of COVID-19 pandemic on dental education: online experience and practice expectations among dental students at the University of Jordan. BMC Med Educ. 2021;21(1):151.

26. Peine A, Kabino K, Spreckelsen C. Self-directed learning can outperform direct instruction in the course of a modern German medical curriculum: results of a mixed methods trial. BMC Med Educ. 2016;16:158

27. Thomas A, Shenoy MT, Shenoy KT, et al. Survey among medical students during COVID-19 lockdown: the online class dilemma. Int J Med Students. 2020;8(2):102-106.

28. Qarajeh R, Tahboub F, Rafie N. The effect of COVID-19 pandemic on US medical students in their clinical years. Int J Med Students. 2020;8(2):172-174.

29. Nguyen Tran Minh D, Pham Huy T, Nguyen Hoang D, et al. COVID-19: experience from Vietnam medical students. Int $\mathrm{J}$ Med Students. 2020;8(1):62-63.

30. Büyükdere AK. Diş hekimliği fakültesi öğrencilerinin öğrenme stillerinin iki farklı yöntemle analizi. J Dent Fac Atatürk Uni. 2018;28(3):371376.

31. Gaman MA, Ryan PM, Bonilla-Escobar FJ. To stay at port or to go to sea: are clinical clerkships a double-edged sword during the COVID-19 pandemic? Where do we go from here? Int J Med Students. 2020;8(1):92-95.

32. Frith $\mathrm{KH}, \mathrm{Kee} \mathrm{CC}$. The effect of communication on nursing student outcomes in a web-based course. J Nurs Educ. 2003;42(8):350-358.

33. Lu D, Lin Z, Li Y. Effects of a web-based course on nursing skills and knowledge learning. J Nurs Educ. 2009;48(2):70-77.

34. Samra RK, Nirola A, Verma A, Nagpal A, Thakur M. Dental students Perception on the impact of E-learning in continuing dental education during the current pandemic scenario. Indian J Dent Sci. 2021:13(2):61-72

35. Cao W, Fang Z, Hou G, et al. The psychological impact of the COVID-19 epidemic on college students in China. Psychiatry Res. 2020;287:112934 